\title{
Environment, Islam, and women: a study of eco-feminist environmental activism in Pakistan
}

\author{
Zeenat Abdul Haq ${ }^{1} \cdot$ Muhammad Imran $^{1,2}$ (D) $\cdot$ Shabbir Ahmad $^{1} \cdot$ Umer Farooq $^{3}$
}

Accepted: 4 September 2020 / Published online: 21 October 2020

(C) Outdoor Education Australia 2020

\begin{abstract}
This study aimed to discuss a better understanding of existing levels of Islamic environmental behavior in the perspective of eco-feminist environmental activism in Pakistan with the analysis of existing literature, media reports, NGOs' environmental movements, and the environmental activists' campaigns. Women, in the world generally and Pakistan particularly, have the most appropriate pro-environmental behavior concerning the cultural eco-feminist dimensions. This study will address the radical reasons for climate change as demographic changes, deforestation, pollution, and population growth along with their solutions from the Islamic perspective. Women as the ecofeminism activists must be the part of policy matters and their implementation structure as the first-hand companions of nature and social culture.
\end{abstract}

Keywords Islam $\cdot$ Eco-feminism $\cdot$ Pakistan $\cdot$ Climate change $\cdot$ Environmental activism

\section{Introduction}

Since the last four decades, theology and environment have been focused comparatively where the environmentalists have leveraged different religious and spiritual values and traditions to provoke environmental activism and its awareness. Various studies and researches have discussed the theological foundations of Islamic environmental traditions and values (Marsi 1992; Ammar 2000; Haq 2001; Nasr 2001; Ammar 2017). This paper is an attempt to contribute to the environmental activism in Pakistan from an ecofeminist perspective, under the Islamic teachings and human behaviors

Muhammad Imran

imranjoyia76@gmail.com; imranjoyia@sjtu.edu.cn

1 Department of English, The University of Sahiwal, Sahiwal, Pakistan

2 School of Foreign Languages, Shanghai Jiao Tong University, 800, Dongchuan RD. Minhang District, Shanghai, China

3 Department of English, University of Sargodha, Sargodha, Pakistan 
towards them. Many scholars have discussed awareness and behaviors as Muslim behaviour towards environmental activism such as Ozdemir (1998), Khalid (1992), Aftab (2001), Al-Jayyousi (2012), Aftab 1994 and Foltz (2013) through various aspects of Islam and environmental activism. However, the present paper discusses Muslim behaviour towards environmental activism in Pakistan in particular and in Islamic theology generally.

In Pakistan, according to the Food and Agriculture Organisation of the United Nations (FAOUN), only 281 per $\mathrm{Km}^{2}$ area are available for the 180 million people. The rapid changes in geographical features, climate change, deforestation, and pollution are affecting the country (2019) in the form of the social and economic crash, and ultimately human conditions. It forced over ten million people to migrate towards safe places (Climate Emergency Institute 2017; Climate Change, Mobility, and Women's Economic Empowerment in Pakistan 2018).

The environmental groups along with the middle-class, until the mid-twentieth century during the industrial and urban development were concerned about preservation, pollution, and wildlife protection of nature (Elliott 2020). This aptitude from the grass-root level proposed as a feasible solution. Joint ventures from the state, NGOs, educational complexes, social sector, and ecofeminist activists are the compatible approaches to address the emerging humanitarian catastrophe. Eco-feminism is the base to discuss the women's environmentalists as environmental caretakers. In comparison, the paper will go through the environmental frames of Egypt and Turkey due to the similar demographics, religious background, and developmental challenges. Secondary literature as research papers, articles, media reports, and web blogs are the sources of information. The findings will help the Pakistani environmentalists, social activists, government, and common people to address the environmental issues for their solution.

The French feminist, Francois d' Eaubonne coined the term 'Eco-feminism' in 1974 (Hosseinnezhad 2017). Women who were against the exploitation of nature initiated this movement to protect their mother nature. Ecofeminism continued to develop, in the 1980s radical eco-feminists linked to nature and women with adjustable power; and encourages their exploitation for economical labor and resources, respectively (Imran and Chen 2020; Miles 2018). The cultural ecofeminist, the second school of thought, encourages the affable relationship between women and nature as nurturer and provider of food that society must value. It was extracted from nature-based religions and social hierarchies (Elliott 2020).

The religion Islam emphasized to maintain the balance and justice in every respect of life, especially human dealings with nature, as in the Holy Quran, He (Allah) advised:

Besides, establish weight in justice and do not make deficient the balance.

(Qur'an 55: 9)

Justice and balance are fundamental conditions for a smooth system and future survival of the universe. Humans must implement them in all aspects of their life; including the environment (Alpay et al. 2013).

Women, being the house managers, maintain this balance, as for the environment is the place to live, work, and re-establish the social and religious beliefs of life (Vasi 2008). Failing to maintain the ecological balance, human actions caused serious 
environmental catastrophes like global warming, floods, earthquakes, landslides, water drought, pollution, disturbance in eco-system, fewer shelter facilities, and pandemics in this century (Miles 2018).

As Quran enlightened, "And that there is not for man except that [good] for which he strives" (Qur'an 53:39). Therefore, humans, as the guardian and trustees of nature, need to maintain the ecosystems with great efforts and personal changes. Waste can be easily reduced by recycling. Water conservation and plantation can secure other natural resources and soil drought (Rahman 2015).

\section{Role of women in environmental activism in Pakistan}

Women are engaged in the environmental activism movement throughout the world, out of which ecofeminism is the one social derivation. As a social movement, it is rooted in environmental and feminist ethics (Hosseinnezhad 2017). In the rush of multiple disciplinary kinds of research as geography, political ecosystem, and poststructuralism, it established an alternative eco-gender solution, opposite to the perspective of male domination against the environment and women (Imran et al. 2020; Hosseinnezhad 2017).

One group of feminists worried about the gender classification of cultural ecofeminism that may promote exploitation while the other group emphasized the naturebased religion. Some of them were against the idealization of nature from the perspective of organic farming. This bifurcation of the movement provided numerous explanations of ecofeminism (Miles 2018; Eckstein et al. 2018). They addressed the issue of different cultures and religions for a rational arrangement. Women, on the other hand, concentrated on local cultures and religious studies according to their natural and social roles, as mothers and custodians (Miles 2018). She naturally protects her environment and participates in economic growth like cattle farming, fishing, producing, and marketing of natural food and herbs. She executes her domestic responsibilities like cooking, gathering fuel, transporting pure water, nurturing children, and elders.

This article is based on cultural ecofeminism. According to the sixth Population and Housing survey, men ratio crossed the women $51 \%$ by $49 \%$ in Pakistan (2017). In modern days, leading women ecofeminist environmental activists are more concerned about environmental issues especially when it comes to their children's health and protection. For example, Rahman is of the view that women's environmental knowledge, regarding environmental regeneration, is disregarded due to the patriarchal ideologies about Islam. Their environmental knowledge can execute climate change issues, more effectively. In the case of ecological degradation, they are primarily affected, as land is a means of livelihood for them. For her, this global crisis can be negotiated by togetherness, as the earth is a shared space for all the organisms (Hussain 2020).

She is the advocate of outdoor activity to promote pro-environmental behaviors. Age, education, class, race, gender, and religion must not barricade when it comes to environmental issues. Vasi favored the view that "kids must join in elders regardless of gender" (2008, p. 90).

An independent policy think tank 'Leadership for Environment and Development' (LEAD) Pakistan, on the other hand, founds that the recovery strategies of climate 
change are "gender-blind" as they only consult local male leaders focused on the socioeconomic factors that affect women's environmental performance. They must focus on the environmental conditions that are causing the poverty and women's disempowerment due to air pollution, overcrowded slums, and poor waste dumping services in Pakistan (Lotia et al. 2018). Islam seconds the cultural ecofeminist view by honoring women about their comfort. According to her biological functions (to be a mother), she needs proper nutrition even before her birth. Allah honored men, as they "shall take full care of women..." (Qur'an 4: 34). Accordingly, work is a privilege for women that they can take on it according to circumstances (Khayat 2003; Liobikienè and Mykolas 2019).

Along with deforestation, plastic garbage is another reason of pollution, especially of seawater in Pakistan. It is like death pills for marine animals and causing the hindrance in the sanitation system. In the case of burning, it harmed the air quality index along with the smoke from factories and automobile engines.

Air pollution is another cause of climate change. Smoke is causing 1.3 million deaths due to lung cancer and heart disease. The conditions get worse in Asian countries during the winter season due to smog (the mixture of fog and smoke). Also in this twenty-first century, about $70 \%$ of Asia people are facing sanitation problems (Alpay et al. 2013). Rehman highlighted the existing environmental issues due to the meager dealings, those are causing pandemics; Dengue fever, Congo fever, Dyria, Hepatitis (2015), and now Coronavirus, etc.

As the twenty-first-century environmental movements are negotiating with the diverse economic applications as tourism, trade, and financial investment (Elliott 2020). In Khat Lashkar village, Dadu district, women were participating in the agriculture economy but changing in weather patterns, due to deforestation and pollution, affected their economic freedom, as well (Abubakar 2016). The Brahui women in Baluchistan, recognize 35 medicinal plants that help them to earn some amount as well (Qureshi et al. 2007). Being a part of environmental activism in Pakistan, Mr. Fahad Rizwan has actively participated in planting in urban areas and also promoted environmental awareness among people. In the following Fig. 1, he has been seen eagerly involved in the comping 'Green Pakistan'.

Pakistan is experiencing water cataloging, land erosion, and desertification due to deforestation and pollution. Green Squad, a group of volunteers tried to promote environmental conservation through the plantation, recycling plastic, and the botanical gardening, especially in Islamabad and Rawalpindi regions. The biggest challenge is the saplings' ownership in case of people's response after the plantation season. Even then, they planted about 20,000 saplings in the country by providing awareness to the common people to preserve the remaining forests (Ahmed 2019). The mangrove in Baba and Bhit islands shriveled due to a lack of fresh water (Rahman 2015).

Recently, Karachi has gone through the worst scenario after heavy rainfall on Eid-ulAzha, 2019. ${ }^{1}$ The international media highlighted the busted roads, poor sanitation, water pollution, energy crisis, garbage, and overpopulation. These were injuring the environment and making life difficult, especially of women as part of the economy,

\footnotetext{
${ }^{1}$ Islamic event named as Eid, a day of celebration, after Hajj on 10 Zilhajj. Muslims all around the world sacrifice animals and distribute the meat among poor for Allah in the remembrance of Hazrat Ismail (A.S)
} 


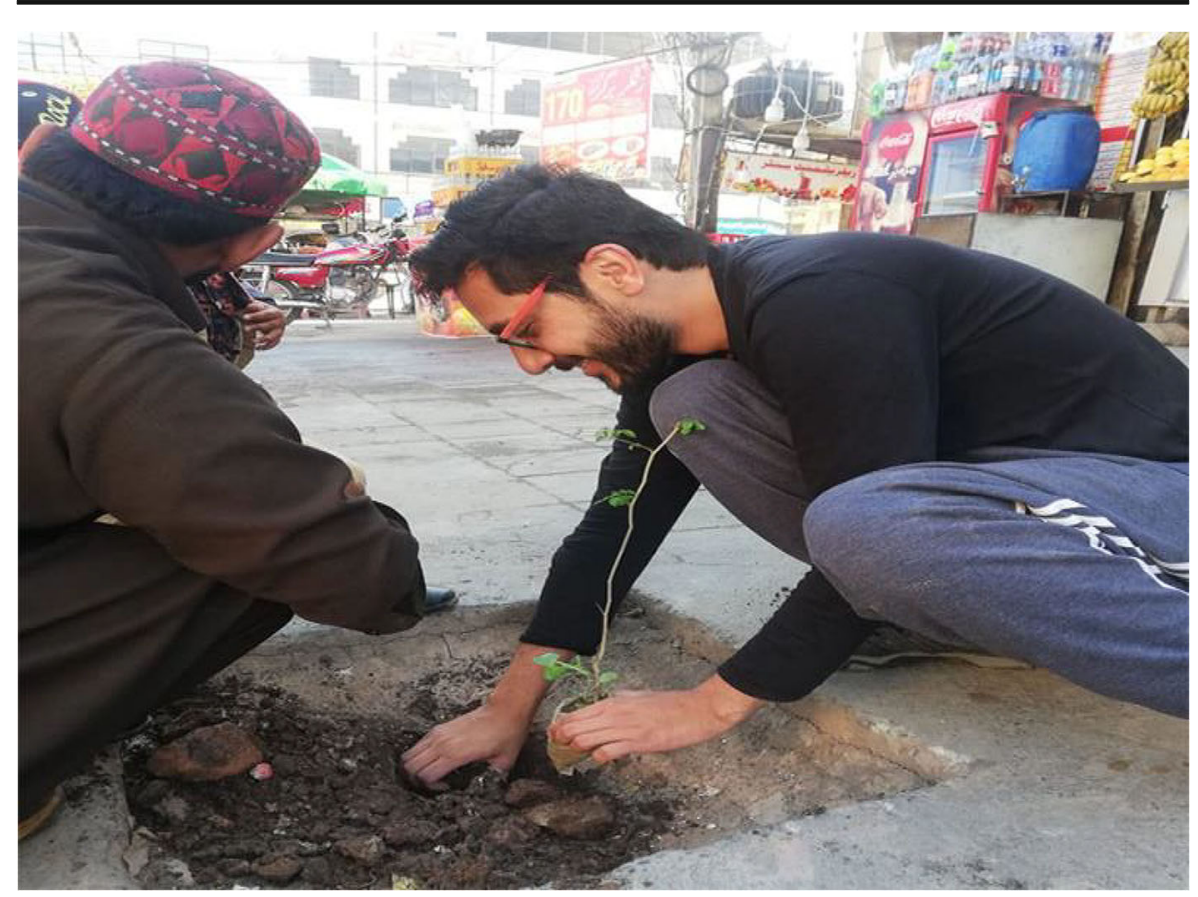

Fig. 1 Environmental activist Fahad Rizwan plants a sapling (Source: Ebad Ahmed/Geo TV/2019)

especially the fishing industry. Shaniera shared the pictures of the hospital's trash on the seaside with the subtitle, 'Now flies and mosquito army attacked the city'. ${ }^{2}$ Dr. Jamali explained in the New York Times, "it is not just affecting the life of common man...they are hounding people" (2019). ${ }^{3}$ Quran clarified it as:

Evil has become rife on the land and at sea because of men's deeds; this so that He may cause them to have a taste of some of their deeds; perhaps they will turn back (from evil)' (Qur'an 55:41).

Humankind's misdeed upset the world's ecological balance and now they are facing natural disasters and pandemics (Alpay et al. 2013).

Therefore, common people must understand their responsibility as the government fixed the large-sized animal-shaped dustbins at the seaside. A solid waste management system must be developed and implemented on an emergency basis to save the economic hub of Pakistan. People must be encouraged to recycle waste, cure the environment, and join environmental groups along with their children. Islam rejected the concept of desolation. Therefore, human beings as social animals are ordered to participate actively for the betterment of society. The following Fig. 2 highlights the human behavior towards environmental protection. The business mafias have been actively engaged in deforestation as shown in Fig. 2. Miss Khan, an award-winning

\footnotetext{
${ }^{2}$ DAWN reported on 8 Sep 2019

3 The executive director of Jinnah Postgraduate Medical Center Karachi, the largest public hospital (Aug 29, 2019)
} 


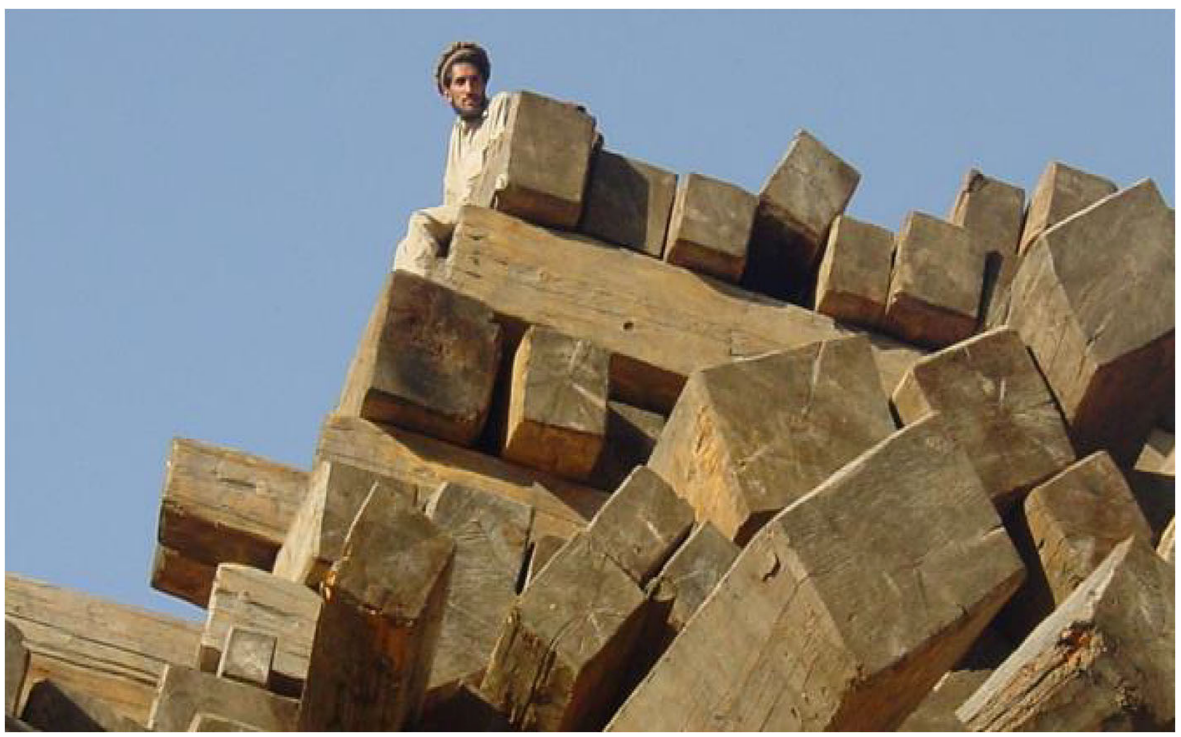

Fig. 2 Deforested wood in Chilas (Source: Rina Saeed Khan/DAWN 2013)

environmental activist, highlighted this case through media and involved the concerned authorities to save forest in Chilas.

Miss Khan raised her voice against deforestation in Chilas in her column 'Murders in Paradise'. According to Miss Khan, due to political involvement, the omission of heavy fines encouraged the timber gangs to move towards the Meadows. To get success, she engaged environmental NGOs: WWF-Pakistan, Sustainable Development Policy Institute, Akhter Hameed Khan Resource Center, and the Bio-resource Research Center, IG Forests' and media houses (Khan 2013).

In rural Sindh, over 133,000 pregnant women have suffered in 2010 floods (April 2017). Kayani, another ecofeminist activist, observed women's tendency to handle the abruptly changing weather patterns. She is assisting them to face the challenges bravely, in the area of domestic animals, dairy development, forestry, poultry, fishing; and their health issues.

Educational institutions are also participating in the ecofeminist environmental activism. They want government attention towards climate change and its effects on Pakistan. Students of Iqra University Islamabad, raised the slogan "Stop Denying, The Earth Is Dying" and "Don't Burn Our Future" (2019). They are using different mediums to increase climate literacy in Pakistan by joining school kids from 15 educational institutions. A Swedish student, Greta Thunberg initiated the movement for environmental protection; and now 1.4 million children, in 100 countries joined it (LEAD 2019). The ecofeminist inspired the children and youth towards leadership and values through their work and TV programs.

Ms. Beg, Pakistan's first hot-air balloonist, and the member of many international environmental groups placed a stage to raise social environmental issues to deal with the global confront. The Indus Consortium and Oxfam Pakistan organized an event for the awareness of the safe environment from the plastic garbage (DAWN 2014). Besides, the Pakistan Press Foundation with the collaboration of an NGO distributed 
more than 500 environmental friendly shopping bags to spread awareness among people on World Environment Day in 2014 (see Fig. 3).

The 'Global Youth Climate Strike movement' organized a walk with the participation of students, mostly female, against the pace of global warming. After these campaigns, the KPK government banned plastic bags. The movement is also under consideration in Punjab and Sindh, as well. The Federal government also banned them in big shopping malls of Islamabad (DAWN 2014). For climate change awareness, Pakistani female university students also have become an active part of the Global Youth Climate Strike Movement and raised voice for healthy environment change. In Fig. 4, a group of university students holding play cards with different slogans on them became the part of Global Youth Climate Strike Movement in Pakistan.

The Pakistan Environmental Protection Authority (EPA), in 1997, was authorized to activate research projects for the protection of the environment from climate change. The institute was lacking financial and human resources. For instance, the government of Pakistan is now promoting tourism so it must take interest to initiate the research projects on emergency bases. 'Egyptian Green Party' motive can be an inspiration for Pakistani political parties as they are educating people on their environmental rights. They established a new environmental value system and condemned nuclear proliferation. According to cultural ecofeminism, $10 \%$ of female members of the party are playing their natural role in the betterment of the environment, so it begins at home. They engaged their teachers to embrace environmental training at the school level (Vasi 2008, p.74).

\section{Islam and Muslim environmentalism}

Islam as the source of knowledge promotes equality and balance in the social structure. Creator has defined moral responsibilities in the form of Islamic philosophy, presented in the Quran and Sunnah (the actions and sayings of the Prophet, Peace Be upon Him).

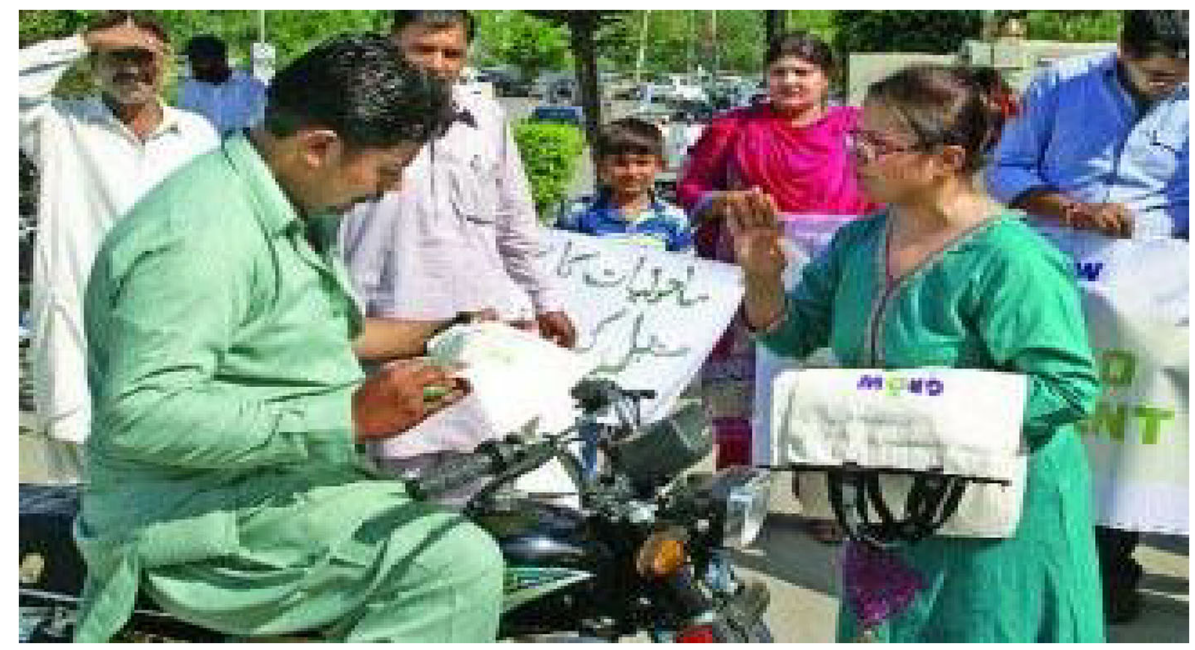

Fig. 3 A volunteer hands an environment-friendly bag to a citizen at Blue Area in Islamabad (Source: Pakistan press foundation, /https://www.pakistanpressfoundation.org/need-protect-environment-stressed/) 


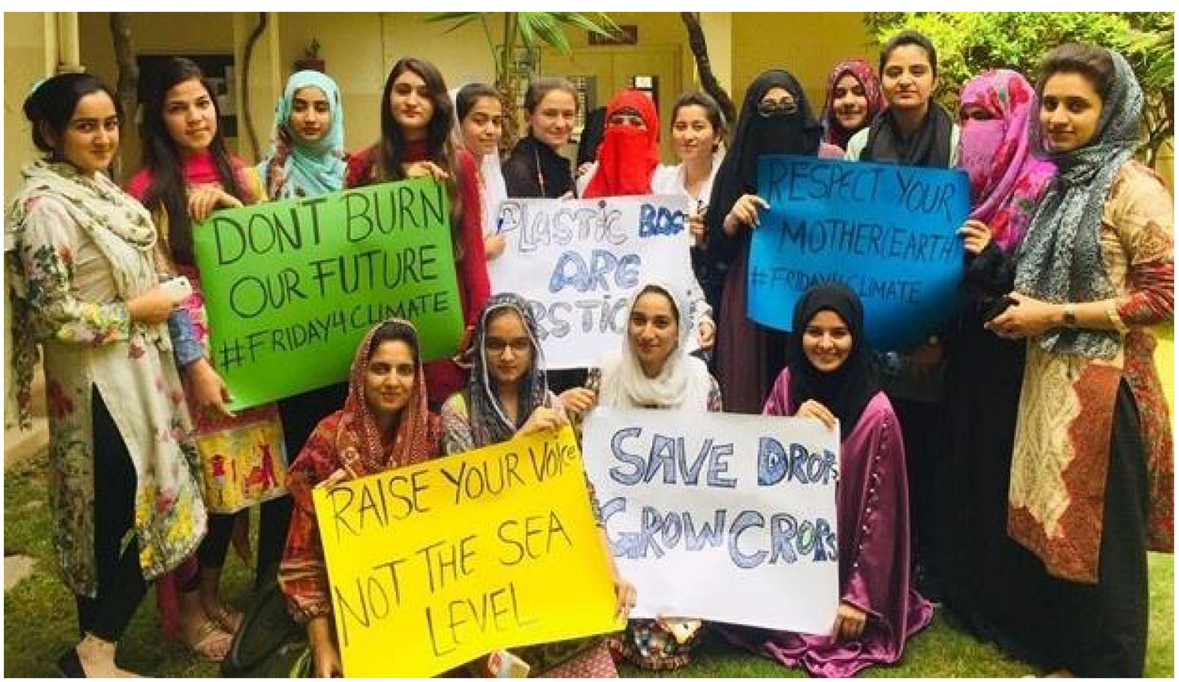

Fig. 4 Pakistani University Students joined global Youth Climate Strike movement (Source: LEAD Pakistan/2019)

Nature as His symbol guides humankind and set some limitations for their behavior, as a control, against the surfeit in life (Vasi 2008). Quran described:

He created man and taught eloquence.

The sun and moon both run with precision.

The stars and the trees all bow down in prostration.

He erected heaven and established the balance ... (Qur'an 55: 3-7).

The environmental ecosystem works within its limits. If the sun, the moon, the stars did not follow the designed pattern, the life function on earth would be unattainable. It is the ethic of balance in nature that man should oblige rather challenge it (Khalid 2010, p. 2). Humans are held responsible for their actions, "Will the reward for doing good be anything but good?” (Qur'an 55: 59; Khalid 2010, p. 7).

Therefore, they must facilitate and make sure the equal distribution of natural resources among all living organisms (Haq 2001). As in the case of animals, Prophet Muhammad (PBUH) instructed, "... if you kill, kill well, and if you slaughter, slaughter well." (Vasi 2008, p.56) This act of slaughtering (Zabeeha) is symbolizing animal rights. Islamic environmental ethics are based on social justice and moderation, as He states, "It is He who produces gardens, both cultivated and wild, and palm trees and crops of diverse kinds...pay their dues on the day of their harvest, and do not be profligate. He does not like those who commit excess" (Qur'an 6: 141; Khalid 2010, p. 3).

Islamic cultural and social norms defined gender roles, as well, where no one could meet the stature of a woman being a mother (Vasi 2008). They are supervising the natural environmental assets (Qureshi et al. 2007); as the ecofeminist environmental custodian, home manager, and sometimes-paid employee (Rahman 2015). In famine and inconsistent rainy seasons, they secure water resources, especially in rural areas. They maintain the household territory including food procurement, livestock trellis, sanitary issues, the physical and mental health of the family (Kayani 2017). 
Women along with children squander 300 days for firewood in the Himalayas region (Qureshi et al. 2007) and walk up to 10 miles for water in Sindh (Rahman 2015). It gets difficult to save natural herbs, wood, medicines' fruits, and foodstuff due to deforestation or fires. As recently, CNN reported according to Christian Poirier regarding the Amazon fires, "The vast majority of these fires are human-lit" (Yeung 2019). According to German Watch Global Climate Risk Index, Pakistan lost \$3826.03 million, 0.567\% of GDP, due to its environmental vulnerability in the last two decades (2017).

\section{Environmental ethics and Islam}

The holy Quran endows humans with the roots of an environmental ethic in the form of Islamic values and laws that reflects humans' social, political, punitive, and environmental operations. Nature and environmental ethics are discussed in approximately 500 verses. The Prophet Muhammad's (PBUH) actions guide humanity for an inclusive social order (Vasi 2008). Islamic scholars and Sufis also spotlighted the importance of environmental ethics. Masri advocates animal rights in the light of Quranic verses (Vasi 2008). Nasr, an Iranian environmentalist, was of the view that humans must practice their power within set patterns. Nature is the means of communication between Allah and humans (Haq 2001).

Islam's primary concern is to treat every organism equally to maintain the cycle of the environmental ecosystem. It will automatically multiply positive aspects as tranquility, synchronization, justice, and reverence in the universe. The Islamic beliefs offer a value system that molds the human character and attitudes towards nature. According to Alpay et al. 2013 who citied Hans Jonas, the "ethical vacuum at the core of the contemporary modern culture" (p. 7). According to the moral ecological ethics of religion, environmental action and spiritual revival within humankind are interdependent (Alpay et al. 2013).

\section{Analysis and recommendations}

The global phenomenon of climate change has made the population vulnerable to floods, cyclones, glacial lakes, cloudbursts, famine, sea intrusion, and water scarcity, has gender-differentiated impacts, especially in Pakistan.

For a healthy and balanced environment, forests must cover $25 \%$ of the land. The National Environment Information System (NEIMS) reported that forest ratio shrinks to 4.72 ha in Pakistan since 2000 (2019). As Quran put in plain words, "verily We have created all things in proportion and measure" (Qur'an 54: 49). Islam not only permits the consumption of natural resources but also forbade from reckless spending:

O children of Adam! ...eat and drink, but waste not by excess, for God loves not the wasters (Qur'an 7: 31).

The eating and drinking are the acts of the continuation of our life cycle; even they must not be uncontrolled. The support life components should be utilized in balance, for future survival according to the universal ecology (Alpay et al. 2013). 
In Pakistan, climate change is directly affecting the agriculture sector. Only $27 \%$ area is plowable, out of which only $1 \%$ is permanently cultivated and $6 \%$ area covered animal meadows (2019). According to the 'Global clean campaign' during the last 2 years, 0.2-degree temperature is increased in Pakistan.

Therefore, forestation must be initiated in such a critical situation on the emergency note, in which women can play a vital role, as of kitchen gardening and pot plantation. International Union for Conservation of Nature (IUCN) recognized around 157 protected areas in Pakistan (2018), as well (Table 1).

Nature sets the rain patterns according to human needs but deforestation and pollution changed it that leads the depletion in water resources. The Qur'an makes it clear:

And Allah has sent down water from the sky.

and given life to the dead earth. Indeed in that.

is a sign for people who listen (Qur'an 16: 65).

If every individual will follow the other to cut a tree, hunt an animal, clean the floors with drinking water, or throw away the foodstuffs. It could not be claimed back, the greater part of the polluted and annihilated resources (Alpay et al. 2013). Prophet (PBUH) considered excessive water usage during ablution as a wrong (makruh) ethic. $\mathrm{He}(\mathrm{PBUH})$ clearly explained the Islamic spirit of balance as "...even if you take them on the bank of a rushing river"4 (Alpay et al. 2013, p. 13). Water is declared as the source of life and ecosystem, "And God has created every animal from water: of them, there are some that creep on their bellies; some that walk on two legs; and some that walk on four. Allah creates what He wills. Indeed, Allah is over all things competent (Qur'an 24: 45).

Women's pro-environmental behaviors influence the entire family, being mothers or teachers their first followers are the young children beyond the debate of Urban/rural or modern/traditional. Through the above discussion, it is very clear that females are more involved in energy preservation, organic food production, environmental and healthfriendly cleaners handling, and recycling of used items. Therefore, there is a positive correlation between women and the environment as the ecofeminist culture viewed it. They use everything (water, electricity, or gas) with greater care within their budget. They teach their children to love animals and be careful to use natural resources (Hosseinnezhad 2017).

In 1992, the United Nations Conference on Environment and Development (UNCED) highlight the effects of climate change on communities, especially women and children. They addressed the issue of $\mathrm{CO}_{2}$ that is the major cause of environmental pollution and breathing disease, asthma. The women's presence as part of NGOs was reported all over the world (Buckingham 2004). (Table 2).

Islamic environmental ethics seek social justice in the sustainability of natural resources. The same movement started as 'environmental social justice of natural resources preservation; at the beginning of the twentieth century in West. The youth separation from religion is welcoming serious health and social issues. Nasr (2001) proposed Islamic ethics as a bridge in this case. All types of media and environmental

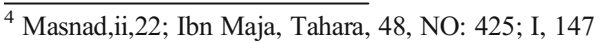


Table 1 Statistics of Protected Land in Pakistan

\begin{tabular}{llll}
\hline Category & Total sites & Total area & Source site \\
\hline National parks & 26 & $1,191,323 \mathrm{ha}$ & wdpa.org \\
Wildlife sanctuaries & 72 & $4,912,531 \mathrm{ha}$ & wdpa.org \\
Game reserves & 66 & $3,026,842 \mathrm{ha}$ & wdpa.org \\
Ramsar protected wetlands & 19 & $1,343,627$ ha & ramsar.org \\
Marine and littoral protected areas & 9 & $1,186,437$ ha & southasiamcpaportal.org \\
Biosphere reserves & 2 & 66,000 ha & earthtrends.wri.org \\
\hline
\end{tabular}

Source: protected areas of Pakistan by Wikipedia (April 2018)

Situated on the shore of the sea

literature are helpful platforms for enduring the environmental consciousness in common people. The walks, seminars, and outdoor recreational activities along with the students and civil society, present a broader perspective. These activities refresh the human mind, provide awareness, and demolish the superficial taboos regarding the women's preambles to environmental changes. They must get involved in the policymaking management team. Conferences and their media coverage, on largescale, can bring together different intellectual, students, civil society, scholars (religious), researchers, journalists, business persons, and environmental communities. The international environmental activists can be called to share their experiences.

From the above discussion, the role of ecofeminist activists' especially Pakistani women is very clear and significant in future development. They are participating in awareness campaigns that woman is the first-hand managers against the climate changes. They can transform their role as competent environmental supervisors to strengthen the economy. As the women in the countryside recognize herbs, soil, and mangroves' importance, in the natural environment. ${ }^{5}$

In the nutrition field, their role is important. They feed the family, so its production, selection, and preparation can provide a healthy nation, as Khayat viewed, "it is women who develop healthy nutritional habits in children" (2003, p. 25). The environmental activists are considering them as the solution suppliers for environmental issues. The mother trained her family in case of personal hygiene and solid waste disposal (Khayat 2003).

They are the best recyclers of used domestic items. They can start kitchen gardening, plant saplings with children's involvement. Being mothers, they can teach all the environmental ethics to their children as do not waste the water during brushing, or bathing by presenting it while they are washing clothes or plates. When she will dump the garbage into the dustbin, children will never throw the wrappers on the floor. They will learn to perform Wazzu (ablution) for Salaat (prayer), which will keep them healthy and fresh. This healthy, clean, and friendly environment will produce responsible citizens. The following Fig. 5 highlights how one can become a reason for an unhealthy environment by keeping an unserious attitude towards environmental ethics.

\footnotetext{
${ }^{5}$ Mangroves are salt-tolerant plants (trees and shrubs) found in the tropical area which have adapted to survive in saline and brackish water. They occur naturally in sheltered coastal areas, such as river mouths, creeks, backwaters, lagoons, bays and estuaries where freshwater meets the seawater (Memon and Shah 2016)
} 
Table 2 Strategies for linking women and environment

\begin{tabular}{ll}
\hline Bringing gender into the environment & Bringing the environment into gender \\
\hline $\begin{array}{l}\text { 1992 United Nations conference on environment } \\
\text { and development 2002 world summit on }\end{array}$ & $\begin{array}{l}\text { 1995 United Nations 4th conference on women and } \\
\text { platform of action UK government gender } \\
\text { sustainable development EU gender } \\
\text { mainstreaming DG XI }\end{array}$ \\
$\begin{array}{l}\text { mainstreaming advice incorporates examples from } \\
\text { the environment field }\end{array}$ \\
\hline
\end{tabular}

Source: ecofeminism in the twenty-first century/Susan Buckingham 2004

United Nations Development Program uncovers the fact that $64 \%$ of women in developing regions are depending on natural resources for their earning (1998). While Asian women are producing $60 \%$ of food in the agricultural sector. In Pakistan, Brahui woman works for $17 \mathrm{~h}$ in the production season (Qureshi et al. 2007). The water quality and quantity are diminishing in desert areas of Pakistan, as Thar and Cholistan. Water pollution is an increasing problem also in urban areas of Pakistan as Karachi, Lahore, Islamabad, Chaman, Sukhar, etc., (Rahman 2015). Unsatisfactory disposal systems of human and industrial wastes and deforestation along with the excessive use of fertilizer chemicals are the main causes of this pollution (Rahman 2015).

In Sindh, even female schools are lacking drinking water, toilets, and boundary walls. Rehman added that now Sindh educational ministry must invest in this sector (2015). A woman is chairing 'The Sindh Environment Protection Agency' whereas in the Balochistan the council has one female member. Most of the NGOs and private sector organizations are following the same trend. They are taking part in environmental issues and policymaking. Education regarding the environment can be started from schools as the 'Green and clean' Pakistan campaign. ${ }^{6}$ According to the 'The National Education Policy 1998', the government emphasized to frame the environmentalrelated curriculum. Northern areas of Pakistan hooked their education policy towards environmental teacher training prospectuses. Balochistan Education Department deposited an Environment Unit (Rahman 2015).

A parallel learning system to normal education is 'Deeni Madrassas' in Pakistan. About 2.5 million children are enrolled in 30,000 madrassas across Pakistan (Rasool 2019). The government and supportive institutions under the madrassas reforms decided to implement the same curriculum. They will learn contemporary subjects along with Islamic education. It is a good move towards the environmental sector as they get the chance to mingle with society to compete with the rest of the world. They will have more awareness concerning Islamic environmental ethics, their implications, and the role of women in social life.

Eco-feminism is of the view that women naturally have a pro-environmental attitude (Imran and Hart 2019). Therefore, the discussion shows that they own every relation faithfully by nature so is the case with plantation. As Rizwan's 'Green Squad' suggested that without care it is a useless activity. Therefore, a compassionate attitude for children and family let them think about the future. It also enables them to take part in political and environmental activism to secure their environment. As a climatefriendly initiative, the government should target women for climate training based on

${ }^{6}$ PM Imran Khan launched a 5-year campaign titled "Clean and Green Pakistan" in Islamabad on Oct.08, 2018. 

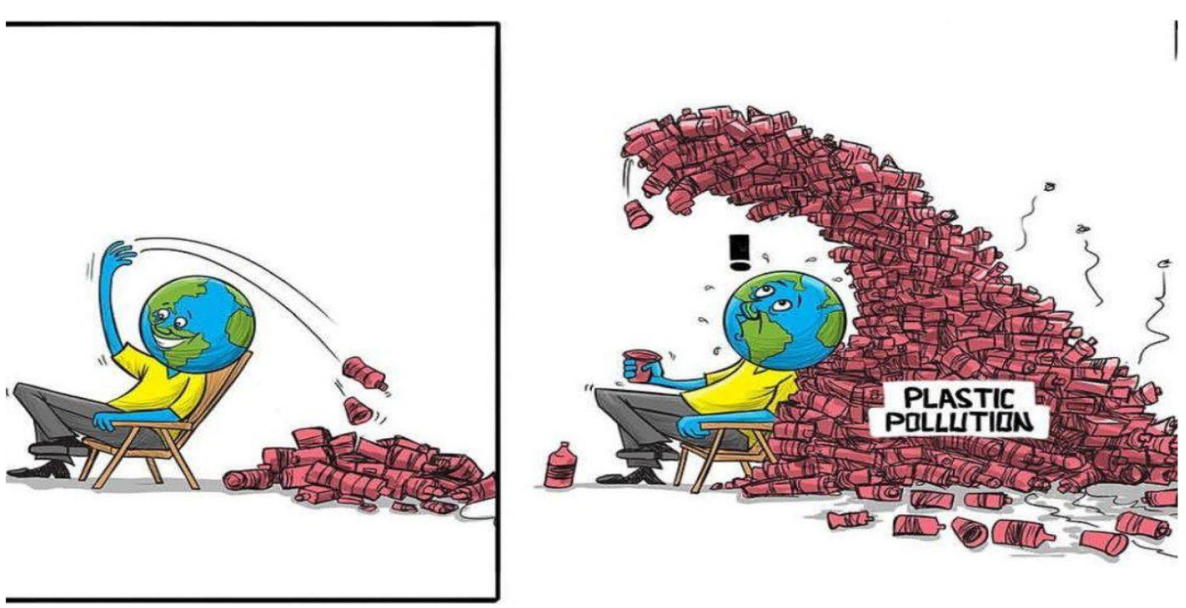

Fig. 5 Source: Google image/Pinterest/Aug. 2019, (https://images.app.goo.gl/nf6yUQ8n4Gy57vud8)

practical data, for the effective policies (Abubakar 2016). The research projects, according to international environmental standards, can be helpful for correct data.

They must be trained to protect themselves from heatwaves. Rainwater harvesting can address water insufficiency issues. As agents of change they can combat climate exposures, more effectively (Abubakar 2016). Ecofeminist environmental activists can actively play a vital role in environmental awareness, along with the government. Many women are working as freelance journalists, NGO workers, organizational coordinators, students, anchors, teachers, housewives, and laborers in society.

Different NGOs, environmental groups, and activists, already have taken up many initiatives, where the government also promised to support them but practically it requires more effort. Minister of State for Climate Change, Zartaj Gul, commented on the Green Squad initiatives that the government would support such young environmental groups through funding. On this note, Rizwan just smiled as there is still no support for them (Ahmed 2019). These types of promises and attitudes discouraged the youth and ecofeminist environmentalists, activists. Therefore, the government must end up the promised tasks, and reforms must be implemented, which result depends on its continuity.

To meet the global environmental challenges, Pakistan included legislation, the Climate Change Act 2017, in the constitution. This act enables it to accept and address climate change as a serious issue. According to a United Nations report, in the next 4050 years, it will cost Pakistan $\$ 10.7$ billion (Buhne 2017). The only implementation of the law can mitigate the effects of climate change in Pakistan until 2042 (Buhne 2017).

All the initiatives sound good but they must be practiced properly. The federal government must engage provinces to integrate environmental ethics in the teaching curriculum like Balochistan and Northern areas of Pakistan. An optional subject at the secondary level can be helpful for students' understanding. The curriculum of general science from the primary level and geography from the intermediate level can be upgraded with environmental concepts. Social and electronic media, especially the entertainment sector must produce environmental-related content for the common people, regardless of gender and age factors. Sharif and Medvecky observed that 
Pakistani media must not confine the climate-related issues to incident-oriented coverage like floods, famine, weather forecasts, press briefings, or walks (2018). The social sector and government join hands, in this context can bring change to understand climate change.

All the natural balanced patterns of production and consumption must be followed in ecosystems. Excessive consumption, amenity, and spendthrift are not authorized by Allah. According to Alpay et al. (2013), the Quran teaches justice, 1437 years ago, and in present global environmental crises, "it can also provide a knowledgeable and practical slant" (p. 19).

\section{Conclusion}

This article concludes that women's ecofeminist approach is sociable and highly demanding in environmental activism in Pakistan. All humans, according to Islamic teachings, should consider the socio-demographic measures to protect the environment such as save water, control air pollution, plantation, donate money and time for environment-friendly projects.

In the Muslims' view, Prophet Muhammad's (PBUH) life is the real picture of the Quranic view, and He was too generous towards nature and humanity, as well. He advised for plantation as, "If a Muslim plants a tree or sows seeds, and then a bird, or a person or an animal eats from it, it is regarded as a charity (sadaqah) for him" (AlBukhari). Alpay et al. are of the view that all the ethics must be relocated and embraced to find out the solutions to environmental issues (2013).

Deforestation and cultivated land transformation are increasing for cattle farms, industry, and housing societies; due to urbanization and the amounted population. Human structures are adding up in the deconstruction of the environment and its resources. On the other hand, women as the first-hand managers of climate change must be educated regarding ecofeminist environmental issues. As the key supervisors of the family unit, they control excessiveness in every aspect of life to maintain balance and justice in the environment. They educate their children about the environment through their actions, so environmental resolution starts at home.

Recycling of domestic waste can be shaped as the art industry, which will be good for the economy as well. Therefore, waste separation and recycling inclined excessive use of natural resources. According to the natural cycle, every action returns from the same direction that was taken in life. If we are to reverse the deterioration of our environment, then we have to make some hard choices and change our practices. In other words, ecological change is the reflection of personal change. This paper can impart in promoting Islamic environmental ethics as Islam propagates justice and respect for all environmental organisms. Wordsworth, known as the poet of nature said, "Knowing that Nature never did betray the heart that loved her; it is her privilege..."7For environmental education and awareness, media campaigns, outdoor community-related events (conferences, walks, plantation days, etc.), and conventional

\footnotetext{
${ }^{7}$ Lines Composed a Few Miles Above Tintern Abbey, On Revisiting the Banks of the Wye during a tour, July 13, 1798 https:/www.theguardian.com/books/2010/jan/26/william-wordsworth-lines-composed-a-fewmiles-above-tintern-abbey
} 
politicization can be opted. Practical and solid strategies, regardless of gender and age, are crucial to address climate change and public awareness. The ecofeminist approach enables Pakistani women to play a key role in promoting environmental activities to mitigate the harmful effects.

Acknowledgments On behalf of all authors, the corresponding author declare that there is no conflict of interest.

\section{References}

Abubakar, M. (2016). Women and climate change. The news. The News International, 29 Apr. 2016. www. thenews.com.pk/print/116402-Women-and-climate-change.

Aftab, S. (1994). NGOs and the environment in Pakistan. SDPI Working Paper, 1-20. Retrieved from https:// sdpi.org/publications/files/W18-NGOs and the Environment in Pakistan.pdf.

Aftab, T. (2001). Text and practice: Women and nature in Islam. In A. Low \& S. Tremayne (Eds.), Custodians of the earth? Women, spirituality and the environment. Oxford: Berghahn Books.

Ahmed, E. (2019). Climate change: The young Pakistani activist striving to save the environment. Retrieved from https:/www.geo.tv/latest/244631-climate-change-a-young-pakistani-environmental-activistbringing-change.

Al-Jayyousi, O. R. (2012). Islam and sustainable development: New worldviews. Surrey: Gower Publishing.

Alpay, S., Özdemir, İ., \& Demirbaș, D. (2013). Environment and Islam. Journal of Economic Cooperation \& Development, 34(4), 1-22.

Ammar, N. H. (2000). An Islamic response to the manifest ecological crisis: Issues of justice. In H. Coward \& D. C. Maguire (Eds.), Visions of a new earth, religious perspectives on population, consumption, and ecology (pp. 131-146). Albany: State University of New York Press.

Ammar, N. H., \& Gray, A. (2017). Islamic environmental teachings: Compatible with ecofeminism. The Wiley Blackwell Companion to Religion and Ecology, Ch.22; pp. 301-314. https://doi.org/10.1002/ 9781118465523.ch22.

Buckingham, S. (2004). Ecofeminism in the twenty-first century. The Geographical Journal, 170(2), 146154. https://doi.org/10.1111/j.0016-7398.2004.00116.x.

Buhne, N. (2017). Environment day. United Nations in Pakistan. https://www.un.org.pk/environment-day/.

Climate Change, Mobility, and Women's Economic Empowerment in Pakistan. (2018) IDRC. www.idrc.ca/ en/research-in-action/climate-change-mobility-and-womens-economic-empowerment-pakistan.

Climate Emergency Institute (2017). Global warming and its impact in Pakistan. Retrieved from https://www. climateemergencyinstitute.com/uploads/global_warming_and_its_impacts_on_Pakistan.pdf.

DAWN, (2014). CDA asked to assess environmental effects of metro bus project. Retrieved from https:// www.dawn.com/news/1093050.

Eckstein, D., Hutfils, M.L., \& Winges, M. (2018). Global Climate Risk Index. 1st Edn., Germanwatch NordSüd Initiative E.V.

Elliott, Lorraine 2020. History of the environmental movement. Encyclopaedia Britannica. Encyclopædia Britannica, Inc. www.britannica.com/topic/environmentalism/History-of-the-environmental-movement.

FAOUN (2019). Pakistan at a glance. Retrieved from http://www.fao.org/pakistan/fao-in-pakistan/pakistan-ata-glance/en/.

Foltz, R. (2013). Ecology in Islam. In A. L. C. Runehov \& L. Oviedo (Eds.), Encyclopedia of sciences and religion (pp. 661-677). The Netherlands: Springer.

Haq, S. N. (2001). Islam and ecology: Toward retrieval and reconstruction. Daedalus, pp. 1-73. https://www. amacad.org/sites/default/files/academy/multimedia/pdfs/publications/daedalus/fall2001/01_fall_ daedalus_Haq.pdf.

Hosseinnezhad, F. (2017). Women and the environment: Ecofeministic approach to environmental attitudes and behavior in Iran. European Journal of Sustainable Development Research, 1(1), 1-7. https://doi.org/ 10.20897/ejosdr.201704.

Hussain, S. (2020). Book review: Place and postcolonial ecofeminism: Pakistani women's literary and cinematic fictions by Shazia Rahman. LSE Review of Books. https://www.blogs.lse.ac.uk/ 
lsereviewofbooks/2020/02/07/book-review-place-and-postcolonial-ecofeminism-pakistani-womensliterary-and-cinematic-fictions-by-shazia-rahman/.

Imran, M., \& Chen, Y. (2020). Arab women's activism and sociopolitical transformation: Unfinished gendered revolutions. British Journal of Middle Eastern Studies. https://oi.org/10.1080/13530194. 2020.1723268.

Imran, M., \& Hart, J. L. (2019). Embroidering within boundaries: Afghan women creating a future. British Journal of Middle Eastern Studies, 46(2), 335-337. https://doi.org/10.1080/13530194.2018.1549003.

Imran, M., Afzaal, M., Chishti, D. M. I., \& Ahmad, D. S. (2020). Political pathways: Factors of successful women leadership in Pakistan. Al-Qalam, 25(1), 244-268.

Kayani, M. A. (2017). Gender dimensions of climate change in Pakistan: Reducing the vulnerabilities of rural women to climate change effects in the Province of Sindh (dissertation). Retrieved from https://pdfs. semanticscholar.org/eb17/f7a26493ed0b627b200d83f2d5eecb320ea9.pdf.

Khalid, F. (2010). Islam and the environment - ethics and practice an assessment. Religion Compass, 4(11), 707-716. https://doi.org/10.1111/j.1749-8171.2010.00249.x.

Khalid, F., \& O’Brien, J. (Eds.). (1992). Islam and ecology. New York: Cassell.

Khan, R. S. (2013). A victory for Pakistani environmentalists. Retrieved from https://www.dawn.com/news/ 1023966.

Khayat, M. H. Al (2003). Women in Islam: Marriage. Scribd. cc.bingj.com/cache.aspx?q=WHO-EM/CBI/ 022/E/G+Distribution:+General\&d=4791585935201653\&mkt=en-WW\&setlang=en-US\&w= hI9yDjSSTGiC9nFMqmO8Y4bysBISIEj8.

LEAD (2019). Pakistani university students take to streets over climate. Retrieved from http://www.lead.org. pk/lead/postDetail.aspx?postid=10394.

Liobikienè, G., \& Mykolas, S. P. (2019). The importance of environmental knowledge for private and public sphere pro-environmental behavior: Modifying the value-belief-norm theory. Sustainability, 11(12), 3324-3342. https://doi.org/10.3390/su11123324.

Lotia, H., et al. (2018). Effects of degraded environmental conditions on women empowerment in slums of four cities of India, Bangladesh, and Pakistan. Lead Pakistan. Empowering Pakistani Women for Growth \& Prosperity. www.lead.org.pk/attachments/presentations/Effects of Degraded Environmental Conditions on Women Empowerment in Slums of Four Cities of India, Bangladesh, and Pakistan by Hina Lotia.pdf.

Masri, A. (1992). Islam and ecology. In F. Khalid, \& J. O'Brien (Eds.), Islam and ecology. London: Cassel Publishers Limited. 1-23.

Memon, S. H., Shah, G. Q. (2016). A handbook on Pakistan's coastal and marine resources. In M. H. Ali (Ed.), A handbook on Pakistan's coastal and marine resources (pp. 3-78). Karachi: MFF Pakistan.

Miles, K. (2018). Ecofeminism. Encyclopcedia Britannica. Encyclopædia Britannica, Inc. www.britannica. com/topic/ecofeminism/Ecofeminisms-future www.britannica.com/topic/ecofeminism.

Nasr, S. H. (2001). Islam and the environmental crisis. Islamic Quarterly, 34(4), 217-234.

Özdemir, İ. (1998). Bediuzzaman Said Nursi's Approach to the Environment. Paper delivered at the Fourth International Symposium on Bediuzzaman Said Nursi: A Contemporary Approach towards Understanding the Qur'an: The Example of Risale-i Nur, Istanbul, Turkey, 20-22 September.

Qureshi, S. A., Khan, M., ul Husnain, M. I., \& Iqbal, N. (2007). Gender, environment, and sustainable economic growth. Pakistan Institute of Development Economics, Islamabad, 46(4), 883-894 Retrieved from http://www.jstor.org/page/info/about/policies/terms.jsp.

Rahman, F. N. (2015). Women: Custodians of the environment. In Women: Custodians of the environment. Retrieved from https://www.researchgate.net/publication/273761817_Women_Custodians_of the Environment.

Rasool, S. (2019). The spirit of madrassa reform. Retrieved from https://nation.com.pk/05-May-2019/thespirit-of-madrassa-reform.

Sharif, A., \& Medvecky, F. (2018). Climate change news reporting in Pakistan: A qualitative analysis of environmental journalists and the barriers they face. Journal of Science Communication, 17 (1), 1-17. https://doi.org/10.22323/2.17010203.

Vasi, J.Z. (2008). Environmentalism and Islam: A Study of Muslim Women in the US (Masters' dissertation), The University of Michigan.

Yeung, J. (2019). Blame humans for starting the Amazon fires, environmentalists say. Retrieved from https:// edition.cnn.com/2019/08/22/americas/amazon-fires-humans-intl-hnk-trnd/index.html.

Publisher's note Springer Nature remains neutral with regard to jurisdictional claims in published maps and institutional affiliations. 
Zeenat Abdul Haq is an M Phil and working as a visiting faculty member in the Humanities Department, The University of Sahiwal, Pakistan.

Muhammad Imran is a Ph.D. scholar at the School of Foreign Languages, Shanghai Jiao Tong University, China, and also working as a Lecturer of literature and gender studies at the University of Sahiwal, Pakistan.

Shabbir Ahmad Ph.D., Assistant Professor of literature and gender studies at the University of Sahiwal, Pakistan.

Umer Farooq is an M Phil in comparative literature from The University of Sargodha, Pakistan. 